DOI https://doi.org/10.30525/978-9934-26-180-0-49

\title{
ГОТОВНІСТЬ МАЙБУТНІХ УЧИТЕЛІВ АНГЛІЙСЬКОЇ МОВИ ДО ФОРМУВАННЯ МІЖКУЛЬТУРНОЇ КОМПЕТЕНТНОСТІ УЧНІВ: ДОСВІД НДУ ІМЕНІ МИКОЛИ ГОГОЛЯ
}

\author{
Давиденко О. В. \\ кандидат педагогічних наук, \\ доцент кафедри германської філології \\ та методики викладання іноземних мов \\ Ніжинський держсавний університет імені Миколи Гоголя \\ м. Ніжин, Чернігівська область, Україна
}

Проблема вдосконалення професійної підготовки вчителів іноземних мов в умовах впровадження сучасної європейської мовної та освітньої політики залишається предметом пильної уваги українських та зарубіжних науковців. Слід зазначити, що Рекомендації Ради Свропи 3 мовної освіти враховано в Державному стандарті загальної середньої освіти й у програмі з іноземної мови для вищих навчальних закладів, які готують учителів та перекладачів. Провідною метою є сприяння багатомовності та міжкультурній компетентості задля підвищення якісного рівня спілкування між європейцями різного мовного й культурного походження, а також уможливлення уніфікованої оцінки рівня знань у межах Європи [2].

На особливу увагу заслуговує рамкова програма оновлених ключових компетентностей для навчання протягом життя, схвалена Європейським парламентом і Радою Свропейського Союзу 17 січня 2018 року [3]. Основні компетенції, визначені в Рамковій програмі, спрямовані на створення засад для досягнення рівноправних і демократичних суспільств. Вони відповідають необхідності забезпечення всебічного та сталого розвитку, соціальної єдності та подальшого розвитку демократичних культур.

У даній публікації ми висвітлимо особливості підготовки фахівців іноземної мови у контексті міжкультурної компетентності у Ніжинському державному університеті імені Миколи Гоголя. У 2013 р. Ніжинський державний університет став учасником спільного проєкту «Шкільний вчитель нового покоління» за ініціативи Британської ради в Україні та Міністерства освіти і науки України. Проєкт мав на меті забезпечити поступову та кардинальну трансформацію підготовки майбутніх учителів англійської мови в закладах вищої педагогічної освіти в Україні. 
Відповідно до наказу Міністерства освіти і науки України від 12 серпня 2015 року №871 у 2016-2019 роках відбулась апробація нового програмного курсу в 14 університетах України, включаючи Ніжинський державний університет імені Миколи Гоголя. Пілотування тривало три роки, результати якого були представлені на конференції у жовтні 2019 року. Одним із висновків є те, що впровадження експериментальної програми дало можливість ЗВО підготувати вчителів нової формації, які налаштовані на роботу в школі, вражають рівнем компетентності педагогічного працівника та здатні до рефлексії власної професійної діяльності. Було прийнято рішення щодо розробки національного рамкового документу для підготовки майбутніх вчителів англійської мови. Шість модулів програми відображають той шлях, який студентам потрібно пройти від тих, кого навчають іноземній мові, до тих, хто їі навчає. Мапу курсу методики відображено у програмі [1, сс. 10-11]. Модуль п’ятий у курсі методики має назву «Особливі аспекти», однією із складових якого є розділ, присвячений підготовці студентів випускного курсу до формування міжкультурної компетентності в учнів [1, с. 81].

Розглянемо особливості втілення даної програми на практиці. Здебільшого нами використовується діяльнісний підхід під час занять, метою якого $є$ спрямованість освітнього процесу на розвиток ключових компетентностей і наскрізних умінь студентів, застосування теоретичних знань на практиці, формування здібностей до самоосвіти і командної роботи, успішну інтеграцію у професійну діяльність. Вважаємо за доцільне розглянути деякі аспекти, які потребують детального розгляду у контексті нашого дослідження.

По-перше, студентам пропонувалося проаналізувати поняття культури, культурної/міжкультурної обізнаності та міжкультурної компетентності. Їхній увазі пропонується теорія культурного айсбергу Е. Холла, за переконанням якого зовнішня, або свідома, частина культури - це те, що ми бачимо, і $€$ верхівкою айсберга та включає поведінку та деякі переконання. Внутрішня, або підсвідома, частина культури знаходиться включає деякі переконання, також цінності та моделі мислення, які лежать в основі поведінки [4]. Культурні відмінності часто можуть призвести до проблем під час викладання в мультикультурних класах, проте модель вирішення проблем «Айсберг» може допомогти вчителям подолати ці непорозуміння. Розуміючи теорію культурного айсберга, ми можемо вирішити або застерегти низку проблем. Окрім цього, студенти знайомляться із поняттями «Big C culture» «small c culture», в основі яких $\epsilon$ культурний айсберг Е. Холла. Це $\epsilon$, безперечно, дотичним, до викладання іноземної мови у школі у межах тем, які вивчаються на тому 
чи іншому освітньому рівні. Для прикладу, під час вивчення теми «Їжа» вчитель може запропонувати учням завдання, спрямоване на отримання детальної інформації про національні страви тієї чи іншої країни та порівняти з рідною країною. Безсумнівно, англійський сніданок набагато відрізняється від українського, а детальне обговорення його інгредієнтів, у свою чергу, надає можливість учням уявити більш цілісну світоглядну картину про дану культуру.

Не менш важливою темою, яка висвітлюється на заняттях з методики викладання іноземної мови, $є$ аналіз стереотипів та упереджень у різних культурах. Підходи, що відстоюють багатомовність і мультикультуралізм, завжди сприяють відкритості по відношенню до іноземної культури та релятивізації власної точки зору. Тому подолання стереотипів та упереджень щодо інших культур часто розглядається як одна з центральних цілей у викладанні іноземної мови, оскільки стереотипи, як правило, надмірно узагальнюють і можуть спотворювати факти. Спростування таких упереджень чи стереотипних суджень часто згадується як одна 3 головних цілей міжкультурного навчання. Однак, повне подолання стереотипів часто не є реалістичним варіантом, оскільки це може бути занадто вимогливим як для вчителів, так і для учнів. Окрім цього, стереотипи можуть виконувати й пізнавальну функцію, а вчитель, у свою чергу як посередник міжкультурного навчання, має розпізнати стереотипні уявлення та піддати їх критичному розгляду. Студентам на заняттях пропонується створити рекомендації для вчителя іноземної мови, які мають бути враховані при викладанні, а саме, вміти аналізувати та виокремлювати можливі міжкультурні стереотипи у навчальних матеріалах; підтверджувати або спростовувати інформацію, подану у підручниках з певними міжкультурними упередженнями; формувати так зване культурне усвідомлення; стимулювати інтелектуальну допитливість стосовно різних культур; заохочувати прихильне ставлення до інших; критично мислити щодо культурних стереотипів тощо.

На особливу увагу заслуговує тема, присвячена обговоренню стратегій, прийомів та, особливо, розробленню різноманітних видів завдань для учнів різних вікових категорій задля підвищення їх рівня міжкультурної обізнаності. Майбутні вчителі іноземної мови усвідомлюють аби отримати всебічне бачення культури, мова якої вивчається, вони повинні репрезентувати учням певну інформацію. Працюючи у невеликих групах на заняттях студенти складають можливий перелік джерел інформації, які можна використовувати як матеріали для навчання тієї чи іншої культури. Серед переліку назвемо відеоматеріали, подкасти, оповідання, казки різних народів, пісні, анекдоти, ілюстрації, сувеніри тощо. Студенти 
відмічають, що використання таких видів завдань на заняттях іноземної мови, як обговорення тем міжкультурного характеру; написання листівок та листів своїм товаришам по листуванню; бесіда із запрошеними гостями, які $є$ представниками іншої культури; читання оповідань чи казок; пошук певної культурологічної інформації; використання ідіом та прислів 'їв безумовно сприяє підвищенню міжкультурної обізнаності школярів. Насамкінець відмітимо, що студенти прийшли до висновку, що вчитель не має представляти культуру як монолітну, а запропоновані учням матеріали повинні відображати різні аспекти культури. Іншими словами, введення навмисних контрастів у культуру може бути корисним, а саме, привабливий проти шокуючого; подібність проти відмінностей; заявлені переконання проти фактичної поведінки тощо.

Підсумовуючи викладене, зазначимо, що методи та прийоми, які використовуються викладачами на заняттях 3 методики навчання англійської мови поступово сприяють готовності майбутніх учителів до формуванню міжкультурної компетентності учнів.

\section{Література:}

1. Типова програма «Методика навчання англійської мови». Освітній ступінь бакалавра. Укладачі: О. Бевз, А. Гембарук, О. Гончарова, О. Заболотна, О. Змієвська, Л. Калініна, І. Каминін, Т. Коноваленко, I. Романишин, I. Самойлюкевич, О. Таран, Н. Тучина, К. Худик/ За заг. ред. С.Шаленко. - Івано-Франківськ: Видавництво НАІР, 2020. - 126 с.

2. Common European Framework of Reference for Languages: Learning, teaching, assessment. Companion Volume with New Descriptors. Strasbourg, France: Council of Europe (Modern Languages Devision), 2018 Retrieved 15 December 2021 from https://rm.coe.int/cefr-companion-volumewith-new-descriptors-2018/1680787989

3. Council recommendations on key competences for lifelong learning. Official Journal of the European Union, 2018 Retrieved 16 December 2021 from https://eur-lex.europa.eu/legal-content/EN/TXT/?uri=uriserv: OJ.C_.2018.189.01.0001.01.ENG\&toc=OJ:C:2018:189:TOC

4. Hall E. T., Hall M.R. Understanding Cultural Differences: Germans, French and Americans. Boston - L.: Intercultural Press, 1990. 224 p. 